\title{
Moral Treatment: Philippe Pinel
}

\author{
Mrs. Sushma. $C^{1 *}$, Dr. Meghamala. S. Tavaragi ${ }^{2}$
}

\section{ABSTRACT}

Philippe Pinel a pioneer, a french psychiatrist, a physician, known as father of modern psychiatry, revolutions psychiatric care of patients with mental illness by introducing concept of moral treatment. Pinel rejected the then prevailing popular notion that mental illness was caused by demonic possession and stated that mental disorders could be caused by a variety of factors including psychological or social stress, congenital conditions, or physiological injury, psychological damage, or heredity. Philippe Pinel for the first time in history of psychiatric patients treated them humanly by unchaining patients known as madmen. This historic event was done for first time in Bicêtre Hospital in 1798 a Parisian insane asylum. In this article a brief history of life and work of pioneer Philippe Pinel is mentioned.

Keywords: Philippe Pinel, the Bicêtre and Salpêtrière, Unchaining, Moral Treatment.

Philippe Pinel was a French psychiatrist and physician who provided a more humane psychological approach to the custody and care of psychiatric patients, referred as moral treatment. Pinel was born in the rolling hills of Jonquières, France. He was the son and nephew of physicians. After receiving a degree from the faculty of medicine in Toulouse, he studied an additional four years at the Faculty of Medicine of Montpellier. He arrived in Paris in 1778. Pinel did much to establish psychiatry formally as a separate branch of medicine. He made notable contributions to the classification of mental disorders and has been described by some as "the father of modern psychiatry". Pinel was also one of the first clinician who believed that medical truth was derived from clinical experience. Pinel considered migrating to America. In 1784 he became editor of the not very prestigious medical journal the Gazette de santé, a four-page weekly. He was also known among natural scientists as a regular contributor to the Journal de physique. He studied mathematics, translated medical works into French, and undertook botanical expeditions.

\footnotetext{
${ }^{1}$ Clinical Psychologist, Dept Of Psychology, Dharwad Institute of Mental Health and Neurosciences (DIMHANS), Dharwad, Karnataka

${ }^{2}$ Senior Resident (Psychiatrist), Dept Of Psychiatry, Dharwad Institute of Mental Health and Neurosciences (DIMHANS), Dharwad, Karnataka

*Responding Author

(C) 2016 I C Sushma, M Tavaragi; licensee IJIP. This is an Open Access Research distributed under the terms of the Creative Commons Attribution License (http://creativecommons.org/licenses/by/2.0), which permits unrestricted use, distribution, and reproduction in any Medium, provided the original work is properly cited.
} 


\section{Moral Treatment: Philippe Pinel}

At about this time he began to develop an intense interest in the study of mental illness. The incentive was a personal one. A friend had developed a 'nervous melancholy' that had 'degenerated into mania' and resulted in suicide. What Pinel regarded as an unnecessary tragedy due to gross mismanagement seems to have haunted him. It led him to seek employment at one of the best-known private sanatoria for the treatment of insanity in Paris. He remained there for five years prior to the Revolution, gathering observations on insanity and beginning to formulate his views on its nature and treatment. Pinel was an Ideologue, a disciple of the abbé de Condillac. He was also a clinician who believed that medical truth was derived from clinical experience. Hippocrates was his model. During the 1780s, Pinel was invited to join the salon of Madame Helvétius. He was in sympathy with the French Revolution. After the revolution, friends he had met at Madame Helvétius' salon came to power. In August 1793 Pinel was appointed "physician of the infirmaries" at Bicêtre Hospital. At the time it housed about four thousand imprisoned men-criminals, petty offenders, syphilitics, pensioners and about two hundred mental patients. Pinel's patrons hoped that his appointment would lead to therapeutic initiatives. His experience at the private sanatoria made him a good candidate for the job.

\section{CONTRIBUTIONS}

Psychiatry: Pinel rejected the prevailing popular notion that mental illness was caused by demonic possession. He stated that mental disorders could be caused by a variety of factors including psychological or social stress, congenital conditions, or physiological injury, psychological damage, physical conditions and heredity. He observed and documented the subtleties and nuances of human experience and emotion. He identified predisposing psychosocial factors of mental ill such as an unhappy love affair, domestic grief, devotion to a cause carried to the point of fanaticism, religious fears, the events of the revolution, violent and unhappy passions, exalted ambitions of glory, financial reverses, religious ecstasy, and outbursts of patriotic fervor. He noted that a state of love could turn to fury and desperation, can cause mania or 'mental alienation'. He also spoke of avarice, pride, friendship, bigotry and vanity.

Moral treatment: Pinel proposed a new, nonviolent approach to the care of mental patients came to be called moral treatment, in the sense of social and psychological factors. He strongly argued for the humane treatment of mental patients, including a friendly interaction between doctor and patient. His treatment was marked by gentleness, understanding, and goodwill. He was opposed to violent methods - although he did not hesitate to employ the straitjacket or forcefeeding when necessary. Pinel expressed warm feelings and respect for his patients: "I cannot but give enthusiastic witness to their moral qualities. Never, except in romances, have I seen spouses more worthy to be cherished, more tender fathers, passionate lovers, purer or more magnanimous patriots, than I have seen in hospitals for the insane".

Pinel visited each patient, often several times a day. He engaged them in lengthy conversations and took careful notes. He recommended close medical attendance during convalescence, and he emphasized the need of hygiene, physical exercise, and a program of purposeful productive work 


\section{Moral Treatment: Philippe Pinel}

for mental patients. He further contributed to the development of psychiatry through his establishment of the practice of maintenance and preservation of detailed case histories for the purpose of treatment and research. Pinel also made the introduction of hospital treatment, doctor's rounds, medical procedures, unchained the insane. Pinel petitioned to the Revolutionary Committee for permission to remove the chains from some of the patients as an experiment,and to allow them to exercise in the open air. When these steps proved to be effective, he was able to change the conditions at the hospital and discontinue the customary methods of treatment, which included bloodletting, purging, and physical abuse. In 1798 Philippe Pinel cut chains from the limbs of patients called "madmen" at the Bicêtre Hospital, a Parisian insane asylum.

Psychotherapy: Pinel's practice of interacting individually with his patients in a humane and understanding manner represented the first known attempt at individual psychotherapy.

Medicine: Pinel was known chiefly for his contributions to internal medicine, especially his authoritative classification of diseases in the textbook Nosographie philosophique (1798), in which he divided diseases into five classes-fevers, phlegmasias, hemorrhages, neuroses, and diseases caused by organic lesions. Besides his work in hospitals, Pinel also treated patients privately as a consulting physician. Pinel's extensive contributions to medical research also include data on the development, prognosis, and frequency of occurrence of various illnesses, and experiments measuring the effectiveness of medicines. Pinel's work on clinical medicine, Nosographie philosophique (1789), was a standard textbook for 2 decades, and several 19thcentury schools of thought on clinical medicine trace their origin to it.

Administration: In addition, Pinel concerned himself with the proper administration of psychiatric facilities, including the training of their personnel. Pinel created an inoculation clinic in his service at the Salpêtrière in 1799 and the first vaccination in Paris was given there in April 1800.

\section{The Bicêtre and Salpêtrière}

Soon after his appointment to Hôspital Bicêtre, Pinel became interested in the seventh ward where 200 mentally ill men were housed. He asked for a report on these inmates. A few days later, he received a table with comments from the "governor" Jean-Baptiste Pussin (1745-1811). In the 1770s Pussin had been successfully treated for scrofula at Bicêtre; and, following a familiar pattern, he was eventually recruited, along with his wife, Marguerite Jubline, on to the staff of the hospice. While at Bicêtre, Pinel did away with bleeding, purging, and blistering in favor of a therapy that involved close contact with and careful observation of patients. Pinel visited each patient, often several times a day, and took careful notes over two years. He engaged them in lengthy conversations. His objective was to assemble a detailed case history and a natural history of the patient's illness. 


\section{Moral Treatment: Philippe Pinel}

In 1795, Pinel became chief physician of the Hospice de la Salpêtrière, a post that he retained for the rest of his life. The Salpêtrière was, at the time, like a large village, with seven thousand elderly indigent and ailing women, an entrenched bureaucracy, a teeming market and huge infirmaries. Pinel missed Pussin and in 1802 secured his transfer to the Salpêtrière. It has also been noted that a Catholic nursing order actually undertook most of the day to day care and understanding of the patients at Salpêtrière, and there were sometimes power struggles between Pinel and the nurses. Pinel created an inoculation clinic in his service at the Salpêtrière in 1799, and the first vaccination in Paris was given there in April 1800.

\section{Publications}

In 1794 Pinel made public his essay 'Memoir on Madness', recently called a fundamental text of modern psychiatry. In 1798 Pinel published an authoritative classification of diseases in his Nosographie philosophique ou méthode de l'analyse appliquée à la médecine. Pinel's classification of mental disorder simplified Cullen's 'neuroses' down to four basic types of mental disorder: melancholia, mania (insanity), dementia, and idiotism. Later editions added forms of 'partial insanity' where only that of feelings which seem to be affected rather than reasoning ability. In his book Traité médico-philosophique sur l'aliénation mentale; ou la manie, published in 1801, Pinel discusses his psychologically oriented approach. In 1802 Pinel published La Médecine Clinique which was based on his experiences at the Salpêtrière and in which he extended his previous book on classification and disease.

\section{HONOURS AND AWARDS}

In 1795 Pinel had also been appointed as a professor of medical pathology, a chair that he held for twenty years. He was briefly dismissed from this position in 1822, with ten other professors, suspected of political liberalism, but reinstated as an honorary professor shortly thereafter. Pinel was elected to the Académie des Sciences in 1804 and was a member of the Académie de Médecine from its founding in 1820. He died in Paris in 1826.

\section{Clinical approach: Psychological understanding}

The central and ubiquitous theme of Pinel's approach to etiology (causation) and treatment was "moral," meaning the emotional or the psychological not ethical. He observed and documented the subtleties and nuances of human experience and behavior, conceiving of people as social animals with imagination. Pinel noted, for example, that: "being held in esteem, having honor, dignity, wealth, fame, which though they may be factitious, always distressing and rarely fully satisfied, often give way to the overturning of reason". He spoke of avarice, pride, friendship, bigotry, the desire for reputation, for conquest, and vanity. He noted that a state of love could turn to fury and desperation, and that sudden severe reversals in life, such as "from the pleasure of success to an overwhelming idea of failure, from a dignified state-or the belief that one occupies one-to a state of disgrace and being forgotten" can cause mania or 'mental alienation'. He identified other predisposing psychosocial factors such as an unhappy love affair, domestic grief, devotion to a cause carried to the point of fanaticism, religious fears, the events of the 


\section{Moral Treatment: Philippe Pinel}

revolution, violent and unhappy passions, exalted ambitions of glory, financial reverses, religious ecstasy, and outbursts of patriotic fervor.

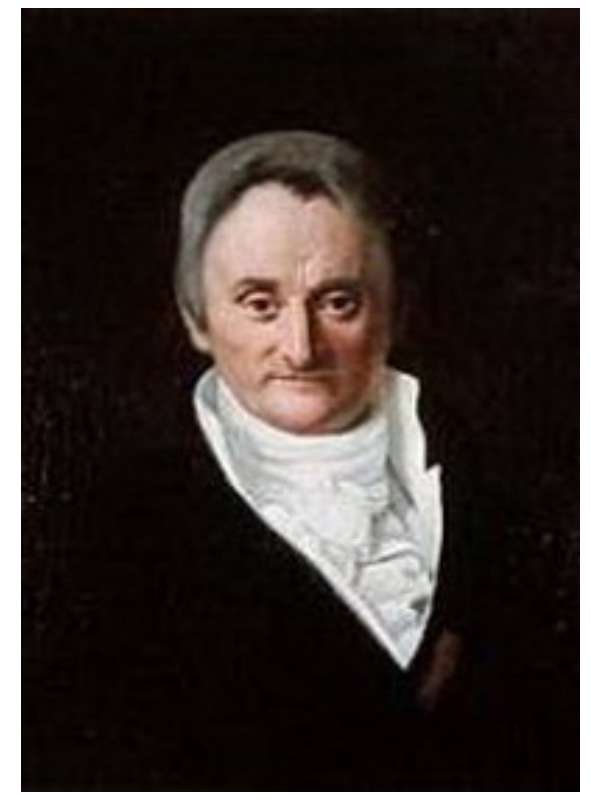

Philippe Pinel (1745-1826)

DOB: April 1745

Place: France

Occupation: Psychiatrist, Physician

Died: 25 October 1826, Paris

Known As

"The father of modern psychiatry, pioneered in "Moral treatment" - the humane treatment of the mentally ill"

\section{CONCLUSIONS}

Philippe Pinel stated that psychiatric illness are caused by various psychosocio and many other reasons other than demonic possession, hence patients should be treated humanly, by non violent ways, and not to chain psychiatric patients. Pinel's most important contribution may have been the observation and conviction that there could be sanity and rationality even in cases that seemed on the surface impossible to understand, and that this could appear for periods in response to surrounding events (and not just because of such things as the phase of the moon, a still common assumption and the origin of the term lunatic).

\section{REFERENCES}

1. Esquirol, É. (1845). Mental Maladies; a Treatise on Insanity. Lea and Blanchard.

2. Foucault, M. Madness and Civilization, or History of Madness.

3. Gerard, D. L. (1997). "Chiarugi and Pinel considered: Soul's brain/person's mind". Journal of the History of the Behavioral Sciences 33 (4): 381. doi:10.1002/(SICI)15206696(199723)33:4<381::AID-JHBS3>3.0.CO;2-S.

4. Hegel.G.W.F. (1790). "Philosophy of mind"

5. Hervey, N. (1986). "Advocacy or folly: the Alleged Lunatics' Friend Society, 1845-63". Med Hist. doi:10.1017/s0025727300045701. PMC 1139650. PMID 3523075.

6. Louis, C. C. (2008). A moral line in the sand: Alexander Chrichton and Philippe Pinel on the psychopathology of the passions. In Fact and value in emotion By Louis C. Charland, Peter Zachar 


\section{Moral Treatment: Philippe Pinel}

7. Philippe, H. (2007). "Animal Economy" Anthropology and the Rise of Psychiatry from the 'Encyclopédie' to the Alienists in Anthropology of the Enlightenment. Wolff L., Marco Cipolloni M. (ed.), Stanford University Press.

8. Pinel, P. (1806). A Treatise on Insanity: In which are Contained the Principles of a New and More Practical Nosology of Maniacal Disorders Than Has Yet Been Offered to the Public. Sheffield, England: W. Todd. OCLC 2320919.

9. Prichard, J. C. (1835). A Treatise on Insanity and Other Disorders Affecting the Mind. Sherwood, Gilbert and Piper.

10. Radden, J. (2000). The Nature of Melancholy : From Aristotle to Kristeva: From Aristotle to Kristeva. Oxford University Press.

11. Scull, A. (1989). Chapter Four: Moral Treatment Reconsidered. Social Order/Mental Disorder: Anglo-American Psychiatry in Historical Perspective (Berkeley, CA: University of California Press).

12. Weiner, D. (1992). "Philippe Pinel's "Memoir on Madness" of December 11, 1794: a fundamental text of modern psychiatry" (PDF). Am J Psychiatry 149 (6): 725-732. PMID 1590490 .

13. Weiner, D. B. (1990). Rousseau, G.S., ed. Nine: Mind and Body in the Clinic. The Languages of Psyche: Mind and Body in Enlightenment Thought (Berkeley, CA: University of California Press).

14. Weiner, D. B., Wallace, E. R. \& Gach, J. (2010). The Madmen in the Light of Reason. Enlightenment Psychiatry: Part II. Alienists, Treatises, and the Psychologic Approach in the Era of Pinel. History of psychiatry and medical psychology: with an epilogue on psychiatry and the mind-body relation. pp. 281-304. ISBN 9780387347080. OCLC 224506545.

15. Weissmann, G. (2008). "Citizen Pinel and the madman at Bellevue". FASEB J. doi:10.1096/fj.08-0501ufm. PMID 18450644.

16. Yuhas, D. (2013). "Throughout History, Defining Schizophrenia Remains A challenge (timeline)". Scientific American Mind. 